Без вреда для экологии;

Социальная программа по обеспечению трудоустройства местных жителей;

Экономические показатели СГД

Скважинная гидродобыча в сравнении с открытым способом имеет высокую производительность предприятия (примерно в четыре раза выше), а удельные капитальные затраты меньше почти в 5 раз.

Структура капитальных затрат и себестоимости при СГД

Себестоимость $1 \mathrm{~m} 3$

Себестоимость: СГД - 93 рублей за 1 м3 пи

$$
\text { ОГР - } 469 \text { рублей за } 1 \text { м3 пи }
$$

Прибыль при СГД:

Себестоимость ОГР(469) - Себестоимость СГД(93) = 376 руб.

$522,1+376=898,1 \mathrm{py} \sigma / \mathrm{M}^{3}$

В Якутии такие работы не ведутся. В Южной Якутии есть благоприятные участки для СГД - например, месторождение Таежное. Для внедрения данной технологии в жизнь необходимо сделаны лабораторные и необходимо сделать натурные испытания. На данный момент ведутся расчеты применительно натуральных условий к экспериментальным для СГД.

\title{
Содержание карты инженерно-геокриологического районирования территории Республики Саха (Якутия)
}

\author{
Спектор В.Б. ${ }^{1}$, д.г.-м.н., Шестакова А.А. ${ }^{1,2}$, к.г.н., Торговкин Я.И. ${ }^{1}$, к.г.н. \\ 1 - Институт мерзлотоведения им. П.И. Мельникова СО РАН, \\ 2. Якутск, \\ E-mail: mpi@ysn.ru \\ 2 - Северо-Восточный федеральный университет, \\ 2. Якутск, \\ E-mail: aashest@mail.ru
}

Под инженерно-геокриологическим районированием понимается пространственная оценка территории с точки зрения изменчивости инженерногеокриологических условий. Инженерно-геокриологические условия определяются свойствами мерзлых и оттаивающих пород, развитием мерзлотно-геологических процессов, состоянием горизонтов межмерзлотных и подмерзлотных вод, быстрой временной изменчивостью температурного поля пород [4]. Актуальность выполнения данной работы связана с ускорением освоения северных (в том числе Арктических) территорий.

Карта инженерно-геокриологического районирования территории $\mathrm{PC}$ (Я) масштаба 1:1500000 была составлена в электронном варианте в формате «ArcGIS 10 version 10.1» (рис. 1) и предназначена для комплексной оценки и использования территории Республики по размещению объектов строительства и направлениям магистральных, транспортных и инженерных коммуникаций, a также для предотвращения и защиты территории от опасных геологических процессов. Карта построена на основе анализа и обобщения основных факторов формирования инженерно-геокриологических условий на территории Республики, каковыми являются 
геолого-структурный, геоморфологический, гидрогеологический и зональноклиматический. Изучение инженерно-геокриологических условий проведено на глубину 10-20 м, соответствующую зоне взаимодействия большинства инженерных сооружений, возводимых и планируемых на территории РС (Я), с криолитозоной. Этот же диапазон глубин совпадает с мощностью слоя годовых колебаний температур криолитозоны территории.

На карте выделены таксоны районирования разного ранга: регионы, провинции, области, районы и зоны. Карта построена по принципу смешанной классификации, когда каждому из классификационных признаков присваивается определенный таксон классификации. Наивысшие классификационные таксоны (таксоны первого порядка) в ранге региона и провинции - были присвоены наиболее крупным элементам рельефа, которые обуславливают тесно с ним связанные экзогенные (и криогенные) процессы. Второй, боле низкий по уровню таксономический уровень - ранг областей - был закреплен за грунтовой составляющей геокриологических условий. Ранг районов был закреплен за криогенной составляющей инженерно-геокриологических условий, отражающей температуру и льдистость грунтов до глубин 10-20 м. Гидрогеологические условия и сейсмичность территории были отражены на схемах, прилагаемых к основной карте.

Легенда карты включает несколько разделов: 1) Инженерно-геокриологическое районирование и опасные криогенные процессы выделяются на карте линейными знаками - линиями разных видов и толщины, ограничивающих регионы и провинции. Интенсивность процессов отражена цветом. Регионы и провинции выделены по морфоструктурному принципу. В пределах территории РС (Я) отмечено 5 регионов:

I. Регион Приморских равнин и низменностей и мелководного шельфа представляет собой четко выраженную в современном рельефе наиболее низкую морфологическую ступень (отрицательную морфоструктуру) [5, с. 12-18]. В пределах региона, на береговой суше и островах выделено 32 провинции, которые отличаются по своему морфоструктурному выражению. Наибольшим распространением среди грунтов пользуются - лессовидные суглинки и супеси с прослоями торфа мощностью 20-30 м [3]. Наиболее опасными процессами являются термокарстовые и береговые абразионные грунты. Температура грунтов уровня нулевых годовых колебаний на береговой суше нередко ниже $-10^{\circ} \mathrm{C}[1,2]$. На мелководном шельфе, вероятно, распространена маломощная прерывистая мерзлота. 


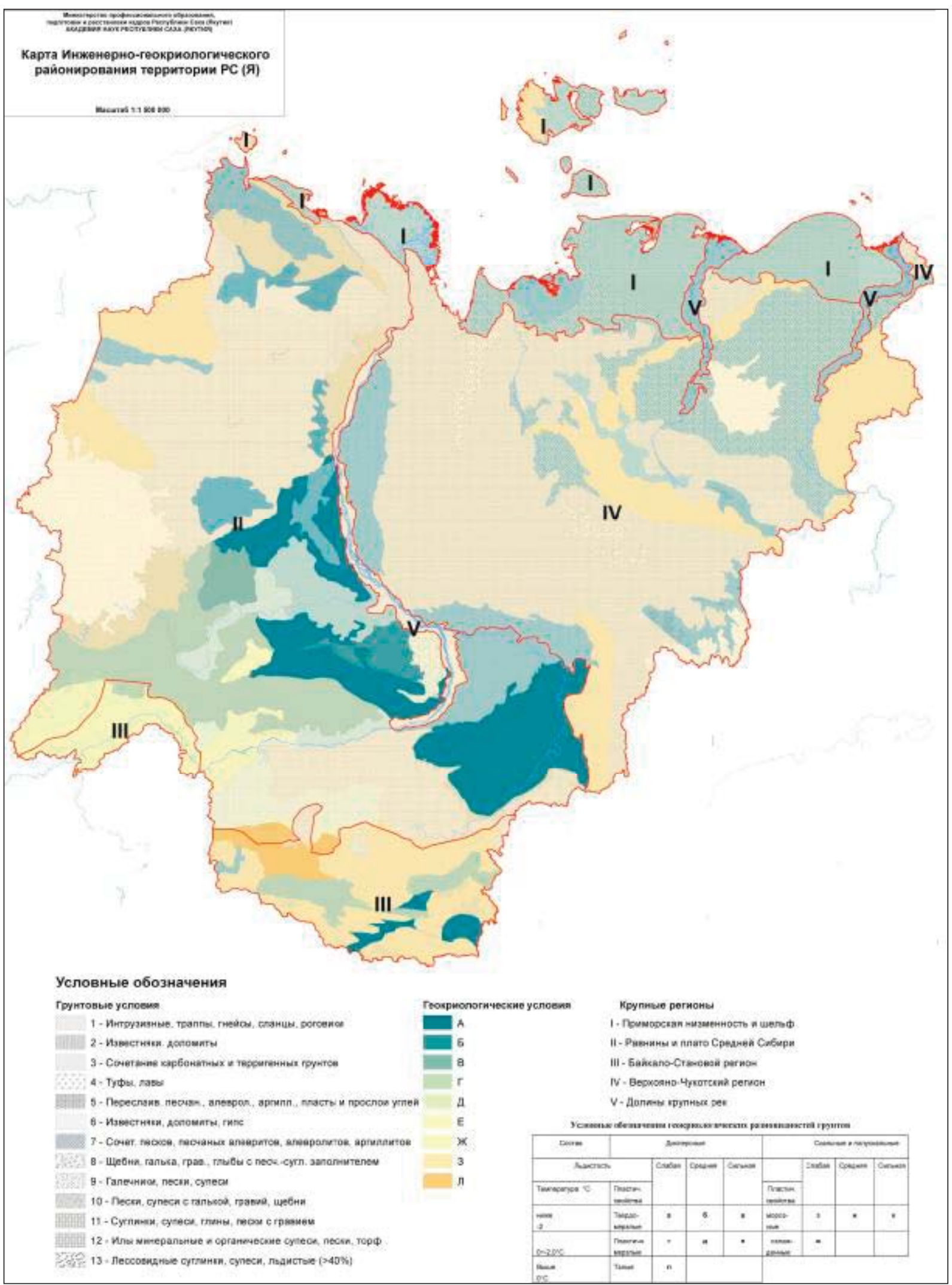

Рис. 1. Карта инженерно-геокриологического районирования территории РС (Я) масштаба $1: 1500000$

II. Регион равнин и плато Средней Сибири включает 30 провинций и охватывает две разные категории морфоструктур: равнины и разновысокие плато, на которых существенно различаются все виды инженерно-геокриологических условий. Регион характеризуется разнообразием и средней интенсивностью экзогенных (криогенных) 
процессов (2-3 балла). В карбонатных породах развит карст. Разнообразны и грунтовые условия: на плато - это скальные грунты, на равнинах - дисперсные и полускальные. Для значительной части территории температура грунтов на подошве годовых теплооборотов составляет $-7^{\circ}--12^{\circ} \mathrm{C}$.

III. Байкало-Становой регион характеризуется высоким рельефом, высокой современной тектонической активностью, что обуславливает здесь широкое распространение обвалов, в том числе и сейсмогенных, осыпей, оползней, курумов (интенсивность 4-5 баллов). Грунты территории - преимущественно скальные: архейские и протерозойские кристаллические породы с подчиненными им площадями рифейских и палеозойских карбонатных пород. В межгорных впадинах распространены мезозойские полускальные породы. Регион относится к зоне прерывистой мерзлоты.

IV. Верхояно-Чукотский регион характеризуется горным рельефом и, соответственно, развитием обвально-осыпных процессов (4-5 баллов). Преимущественное распространение имеют полускальные грунты, среднегодовая температура которых не поднимается выше $-5^{\circ}$ С. Льдистые и высокольдистые дисперсные грунты отмечены в межгорных впадинах и на площади перехода к Арктическим низменностям.

V. Tрансрегиональные области - долины крупных рек (рр. Лена, Индигирка и Колыма).

2) Условные обозначения литогенной составляющей инженерногеокриологических условий на карте приняты штриховым знаком (рис. 1). Номера знаков, которые показаны на карте, приведены в таблице 1.

Таблица 1 (фрагмент)

Обозначения грунтовой составляющей инженерно-геокриологических условий

\begin{tabular}{|l|l|l|c|}
\hline \multicolumn{1}{|c|}{ Класс } & \multicolumn{1}{|c|}{ Группа грунтов } & \multicolumn{1}{|c|}{ Литология } & $\begin{array}{c}\text { № в } \\
\text { услов } \\
\text { ных }\end{array}$ \\
\hline Скальные & силикатные & $\begin{array}{l}\text { интрузивные, траппы, гнейсы, } \\
\text { сланцы, роговики }\end{array}$ & 1 \\
\cline { 2 - 4 } & $\begin{array}{l}\text { карбонатно- } \\
\text { карстовые }\end{array}$ & известняки, доломиты & 2 \\
\hline Пые & $\begin{array}{l}\text { сочетание } \\
\text { скальных и } \\
\text { полускальных }\end{array}$ & $\begin{array}{l}\text { сочетание карбонатных и } \\
\text { терригенных грунтов: известняки, } \\
\text { мергели, доломиты, с прослоями } \\
\text { аргиллитов, алевролитов, песков, } \\
\text { конгломератов }\end{array}$ & 3 \\
\cline { 2 - 5 } & вулканогенные & туфы, лавы & 4 \\
\hline
\end{tabular}

3) Условные обозначения криогенной составляющей инженерногеокриологических условий на карте выделены буквенным и цветовым знаком (рис. 1). Содержание этих знаков отражено в таблице 2. 
Таблица 2

Условные обозначения геокриологических разновидностей грунтов

\begin{tabular}{|c|c|c|c|c|c|c|c|c|}
\hline Состав & \multicolumn{4}{|c|}{ Дисперсные } & \multicolumn{4}{|c|}{ Скальные и полускальные } \\
\hline \multicolumn{2}{|c|}{ Льдистость } & $\begin{array}{l}\text { Сла } \\
\text { бая }\end{array}$ & $\begin{array}{l}\text { Сред } \\
\text { няя }\end{array}$ & $\begin{array}{l}\text { Силь } \\
\text { ная }\end{array}$ & & $\begin{array}{l}\text { Сла } \\
\text { бая }\end{array}$ & $\begin{array}{l}\text { Сред } \\
\text { няя }\end{array}$ & $\begin{array}{l}\text { Силь } \\
\text { ная }\end{array}$ \\
\hline $\begin{array}{l}\text { Темпер } \\
\text { атура, } \\
{ }^{\circ} \mathrm{C}\end{array}$ & $\begin{array}{l}\text { Пластич. } \\
\text { свойства }\end{array}$ & & & & $\begin{array}{l}\text { Плас } \\
\text { тич. } \\
\text { свой } \\
\text { ства } \\
\end{array}$ & & & \\
\hline ниже -2 & $\begin{array}{l}\text { твердо- } \\
\text { мерзлые }\end{array}$ & $\mathbf{A}$ & $\mathbf{5}$ & $\mathbf{B}$ & $\begin{array}{l}\text { мороз } \\
\text { ные }\end{array}$ & 3 & И & $\mathbf{K}$ \\
\hline$-2,0 \div 0$ & $\begin{array}{l}\text { пластичн } \\
\text { о- } \\
\text { мерзлые }\end{array}$ & $\Gamma$ & Д & $\mathbf{E}$ & $\begin{array}{l}\text { охлаж- } \\
\text { денные }\end{array}$ & Ж & & \\
\hline выше 0 & талые & $\boldsymbol{\Omega}$ & & & & & & \\
\hline
\end{tabular}

Определяющим критерием состояния мерзлых грунтов для строительства наземных сооружений показан интервал температур равный $0 \div-2^{\circ} \mathrm{C}$, который контролирует пластические свойства мерзлых грунтов, определяя их твердомерзлое и пластично-мерзлое состояние. Представляется целесообразным выделение охлажденных грунтов в скальных и полускальных грунтах, в которых имеют место минерализованные воды (криопэги).

Предлагаемое исследование представляет собой одну из первых работ по анализу инженерно-геокриологических условий на территории Республики Саха (Якутия). На всей территории Республики впервые выделены районы с максимальной активностью криогенных процессов, охарактеризованы грунтовые условия, их геоморфология, гидрогеология и сейсмичность. Дальнейшие шаги в этом направлении должны заключаться в составлении серий карт районирования криолитозоны по возможности возникновения экологических ситуаций в различных природно-технических системах на территории Республики Саха (Якутия).

Список литературы:

1. Геокриологическая карта СССР масштаба 1:2500000. Картпредприятие, 1997.

2. Геокриология СССР. Т.ІІІ. Средняя Сибирь. - М.: Недра, 1989. - 414 с.

3. Геология Якутской АССР. М.: Недра, 1981. 300 с.

4. Основы геокриологии. Ч.5: Инженерная геокриология / Ред. Э.Д. Ершов. М.: Изд-во МГУ, 1999. - 526 с.

5. Тектоника, геодинамика и металлогения территории Республики Саха (Якутия). - М.: МАИК «Наука/Интерпериодика», 2001. - 571 с.

Работа выполнена при поддержке Правительства и Академии наук Республики Саха (Якутия). 